\title{
The role of localism in the development of regional structures in post-war Finland
}

\author{
Ari-Veikko Anttiroiko \& Pekka Valkama \\ University of Tampere, School of Management, Tampere, Finland
}

\begin{abstract}
A perceived need for a wider resource base for territorial governance has initiated a new regionalisation trend throughout the developed world. Local governments are frequently opposed to such a development. This paper presents an institutional analysis of how Finland's tradition of strong localism has affected the forms, processes and results of regionalisation. The paper argues that path dependence in the form of localist influence from the mid-1990s until the mid-2010s led to an incremental development of regional structures. However, things changed in 2015 due to a historical decision by the centre-right government to establish a new tier of elected regional government. This was due to the diminished credibility of localism given the realities of contextual pressures and government's attempts to improve efficiency and competitiveness. Unless radical political surprises intervene, this will radically undermine the role of local government as a stronghold of representative localism.
\end{abstract}

Keywords: regionalisation, regional government, new regionalism, localism, new localism, local government, self-government, decentralisation, reform, institutionalism, path dependence, critical juncture, Finland

Citation: Anttiroiko, A.-V. \& Valkama, P. (2017). The role of localism in the development of regional structures in post-war Finland. Public Policy and Administration, 32(2), 152-172. DOI: https://doi.org/10.1177/0952076716658797 


\section{Introduction}

Historically, regionalisation has sought to ease the tension between ethno-territorial interests and the central state, while during the post-war decades the emphasis has been increasingly on both strengthening regional development in response to globalisation of the economy and creating efficient political-administrative units capable of providing those public services that require a large population base, such as specialist medical care (Tomblin, 2007; Prytherch, 2009; Page, 1991).

Regionalisation has generally been strongly opposed by local actors fearing to lose control of local affairs. Such opposition has been manifested in most of the major territorial reform cases in Europe (Page, 1991; Bukowski, 2000; Blomqvist and Bergman, 2010; Chorianopoulos, 2012; Hartwich, 2013; OECD, 2014). In this field a bottom-up approach to regionalisation is unique in that it gives local actors a decisive role in territorial reform, as has been the case in Finland, Norway, Iceland and the Netherlands (OECD, 2014). Here we probe this issue through the case of Finland.

Finland serves as an example through which to understand the impact of localism on territorial policy. First, it is a decentralised unitary state where local government is highly influential. Second, Finland's regional government structure has historically been weak, without democratic functions and responsibility for welfare services. These have been addressed through an evolutionary development of complex collaborative arrangements between local authorities, sometimes referred to as second-tier local government. The only case exemplifying genuine ethno-territorial interests in Finland is the autonomous Swedishspeaking region of the Åland Islands, enjoying special arrangements affirmed in 1921 by the League of Nations (see Malloy, 2013). Third, a crucial dynamic aspect is that since the early 1990s Finland has experienced an unprecedented regionalisation wave, resulting in tensional reforms including top-down, negotiated and bottom-up processes. Taken together, these factors constitute a unique real-world case for studying the impact of localism on the local and regional government reform, which is actually rarely discussed in the academic literature.

The literature on Finnish public sector reforms includes analyses of various aspects of national reform of regional structure (e.g. Mennola, 1999; Lähteenmäki-Smith, 2006; Haveri, 2006; Kettunen, 2009; Kull, 2009; Paasi and Zimmerbauer, 2011; Haveri et al., 2015) and of its connections with Nordic and European developments (Hörnström, 2010; 2013; Lind, 2013; 
Kettunen and Kungla, 2005). Considering more comprehensively the body of literature on local government and governance reforms in Finland, numerous publications are in some way relevant to the topic of this article. This includes analyses of reform processes and evaluations of individual reform programmes, although for obvious reasons few are available in English (e.g. Nyholm, 2008; Airaksinen, 2009; Airaksinen and Haveri, 2012; Meklin and PekolaSjöblom, 2013). Nevertheless, we look at this issue from the point of view of localism, for according to public debate, this is decisive in torpedoing or reshaping territorial reforms. Only few academic works discuss localism in Finland (e.g. Andersson and Sjöblom, 2013) and, according to our review, none of these focuses on its impact on regionalisation.

This article aims to shed light on the role of localism in territorial reforms in Finland, a Nordic country with a strong localist tradition built into the post-war development of the welfare society. We will focus on three questions:

(i) What has been the impact of localism on the Finnish local and regional government reform agenda in the post-war era?

(ii) To what extent has localism de facto affected the reshaping of regional structure since the introduction of territorial reforms from the early 1990s onwards?

(iii) What explains the radical turn in territorial reform agenda in 2015 evidenced by Prime Minister Juha Sipilä's centre-right government's decision to establish an elected regional government?

Methodologically, we conduct institutional analysis of the case of Finland (Yin, 2008). Even if such an analysis is based on the context-specific features of the case, it also sheds light on territorial policy reforms in general by enhancing the understanding of the institutional dynamics of such processes, most notably of the impact of localism and of the persistent institutional trajectory and related critical junctures (see Amenta, 2009). In the empirical analysis we focus on path dependence and critical junctures of the territorial reform process and related discourses, drawing empirical data from preparatory legislative materials, evaluation reports and policy documents. The framework for our analysis will be discussed in the next section. 


\section{Theoretical and methodological framework}

\section{Key underpinnings of institutional analysis}

Our approach is rooted in the historical institutional approach to public policy making (see Mahoney, 2000; Amenta and Ramsey, 2010). Institutionalists generally explore how institutions are created and how they structure human behaviour. Historical institutionalists approach this issue by paying particular attention to continuity and change (see Steinmo, 2008). The historical aspect of our analysis concerns not when something happens in a sequence of events but rather the dynamics of public sector reform. Such a perspective goes beyond 'constant causes' or renegotiations without drastic change (Thelen, 2003) by acknowledging that the dynamics of institutional change occasionally produces outcomes that are "the accumulated responses to particular stimuli or other dynamic changes" (Lieberman, 2001).

We discuss a process in which institutional interventions by central government create the preconditions for governmentality, which includes the strategies by which the state tries to render local and regional levels governable (cf. Kingston and Caballero, 2009; Shand, 2015). The other side of the coin is how local governments affect the structural reforms conditioning their own functioning. The setting is thus institutionally mediated and layered. Moreover, rather than institutional regularities, we look for patterns of change, i.e. resistance to change, power to shape reform discourses, and the point at which key actors begin to favour change over the status quo (see Gains et al., 2005).

A standard category of institutional analysis is path dependence. This refers to sensitive dependence on initial conditions, which in the public policy context implies a fixed political or bureaucratic mindset and stickiness of institutional structures. It helps to pay attention to lock-ins and the difficulty of escaping the given institutional trajectory (Henning et al., 2013). It refers to both irreversible and self-reinforcing processes, implying potential incremental changes as necessary adjustments to enable the required functions at the given trajectory without undermining the structural features of the institutional entity, even if it may eventually become suboptimal (Thelen, 2003; Streeck and Thelen, 2005). Interestingly, such self-perpetuating sequences are used by local governments to influence their own politicalinstitutional context, thus, ultimately determining their ability to maintain the status quo. 
Periodisation, another standard tool in historical institutional analysis, serves primarily as a characterisation of a particular transitional period shaped by subtle markers and changes in the spirit of territorial reform (see Lieberman, 2001). Identification of critical junctures has a crucial role in such an analysis. Such junctures refer to periods when actors are briefly faced with a wider range of feasible options having a significant impact on subsequent outcomes (Capoccia and Kelemen, 2007). As we will later show, our case itself implies that, beside major exogenous events such as electoral landslides and radical reforms, we need to pay attention to incremental changes or micro-junctures as a part of the transformation process (Shand, 2015; Thelen, 2003).

Such methodological underpinnings of historical institutionalism enable us to frame our empirical observations and the reading of policy documents. Such an explanatory scheme creates a narrative causal account (cf. Griffin, 1992; Lieberman, 2001) where the nature of causation is essentially historical and conjunctural (Amenta, 2009).

\section{Influence of localist forces}

Our conceptualisation of the influence of local governments and their associations as representatives of modern localism is derived from the discussion of interest group influence (Pedersen, 2013). It asserts that the direction of lobbying (pro-status quo vs. anti-status quo) and the stage of the policy cycle have a great methodological importance (Pritoni, 2014). To identify causalities, we may contrast the goals of an individual reform programme with the actual results, assess the degree of goal attainment, and consider whether the degree of failure was due to by accidents, technical reasons or structural or political factors. This setting implies in general that the more radical change achieved through the reform, the greater the loss to pro-status quo groups. Pritoni's (2014) typology of influence in policy process identifies three forms for pro-status quo groups: veto, negotiation and boycott. To prevent the change an interest group may use veto in agenda setting to make the reform as moderate as possible, or even attempt to avoid politicising the issue in the first place; negotiate its terms by filibustering or bargaining in the decision-making process; and boycott the implementation by various means.

Methodologically, a particularly challenging issue is to identify the major reasons for maintaining the status quo, which may have been other than hypothesised in our analysis. Even if in such complex social processes causalities are interdependent, the representatives of 
local governments and their associations stand out as major players in the national reform discourse. Recent evaluations of municipal and regional reforms in Finland concur with this observation (Haveri, 2006; Nyholm, 2008; Airaksinen, 2009; Kettunen, 2009; Meklin and Pekola-Sjöblom, 2013; Haveri et al., 2015). Moreover, our case has a methodological advantage in this respect, as the measurement of interest representation and lobbying is easier in the case of pro-status quo groups, in cases where the key political actors have a fairly stable position and where the time span is fairly short (Pritoni, 2014).

\section{Reform discourse, agency and institutions}

A distinctive feature of our analysis is the interest in the policy discourse around regionalisation. As contended by Phillips and others (2004, p. 635), “institutions are constituted through discourse and --- it is not action per se that provides the basis for institutionalization but, rather, the texts that describe and communicate those actions." In addition, institutions seek to legitimise their own interests and existence through discourses through which they seek to preserve, transform or reconceptualise social practices (Mayr, 2008). On the other hand, discourses are potentially much more irrational, dynamic and ambiguous than posited by 'old' institutionalisms (Schmidt, 2008; 2010).

Discourses as processes are about political communication and policy construction. Our interest is in the policy sphere, where "the coordinative discourse consists of the individuals and groups at the center of policy construction who are involved in the creation, elaboration, and justification of policy and programmatic ideas" (Schmidt, 2008). What, then, determines the success of the representation and process of a discourse in exerting causal influence by promoting change? According to Schmidt (2008), it is the articulation of the substantive content, such as relevance, adequacy, applicability, and appropriateness. Besides substantive content of discourse, however, we need to consider the related interactive processes within which agents convey their ideas (see Van Dijk, 1997). When applied to the assessment of the success or failure of a policy, it implies that what matters is not only policy viability but also administrative and political viability (Kingdon, 1984).

Process-wise, it is important to convince others of the necessity or appropriateness of a given course of action. In compound polities, where governing activities tend to be dispersed among multiple authorities, as in Nordic unitary states with proportional representation and corporatist structures, the coordinative discourse among policy actors tends to be much more 
elaborate than the communicative discourse to the public (Schmidt, 2008). This view substantiates the ideas presented earlier on historical institutionalism by highlighting the special nature of discourses in policy-making context.

\section{Localism and regionalisation tendencies: from conflict to integration}

Institutionally, localism builds on the premise that the territorial organisation of society should be based on large number of relatively small governments wielding power in issues such as land use regulation, local taxation and public service provision. Regionalisation usually conflicts such a premise in that it transfers some power to regional government with a larger territorial scope and population base. From a localist perspective it is a step towards centralisation (Briffault, 1999). However, the factual developments of intermediary-level political-administrative units may vary considerably, for they can be based on decentralisation of central responsibilities, as seen in continental Europe and the UK, or an aggregation of municipal responsibilities, as in the Nordic countries (Blomqvist and Bergman, 2010; Bertrana and Heinelt, 2013).

Current developments in regionalisation reflect a transition from traditional regional policy based on redistribution and state steering towards a new regionalist perspective (Hörnström, 2013; see e.g. Barnes and Foster, 2012). Such a paradigm shift implies changes in the localregional interface: regional governance structures are more accessible and responsive to local communities than are provincial and national agencies, yet more affordable and effective at instigating change than single community efforts (Markey et al., 2005). This evidently increases local players' interest to engage in the bottom-up style regionalisation associated with New Localism (Rees and Rose, 2015; Pratchett, 2004).

In spite of the emergent aspects of local-regional interface, incipient regionalisation has often been persistently opposed by localist forces. In many cases local authorities fear that under regional authorities they would be too strictly controlled - sometimes even more than under central government (Bukowski, 2000; Chorianopoulos, 2012), which would violate the ingrained ideas of local self-sufficiency and local choice (Moore, 2014; Stewart, 1983). Such fears invoke reactionary localism affecting local actors' orientation towards territorial reforms (cf. Howlett, 2003). In the decentralised welfare society such localism is highly institutionalised and associated primarily with the opportunity of local political élites and 
public managers to shape local public services (Stewart, 1983; Page, 1991). This is undoubtedly one of the critical points of previously mentioned local-regional interface.

\section{Localism in the Finnish political-administrative system}

\section{Local government in Finnish public administration}

The Finnish political-administrative system is fairly decentralised; local governments deliver most of the welfare services, including health care, social services, basic and secondary education, town planning, municipal waste management, libraries, etc. A simplified diagram of the system is presented in Figure 1.

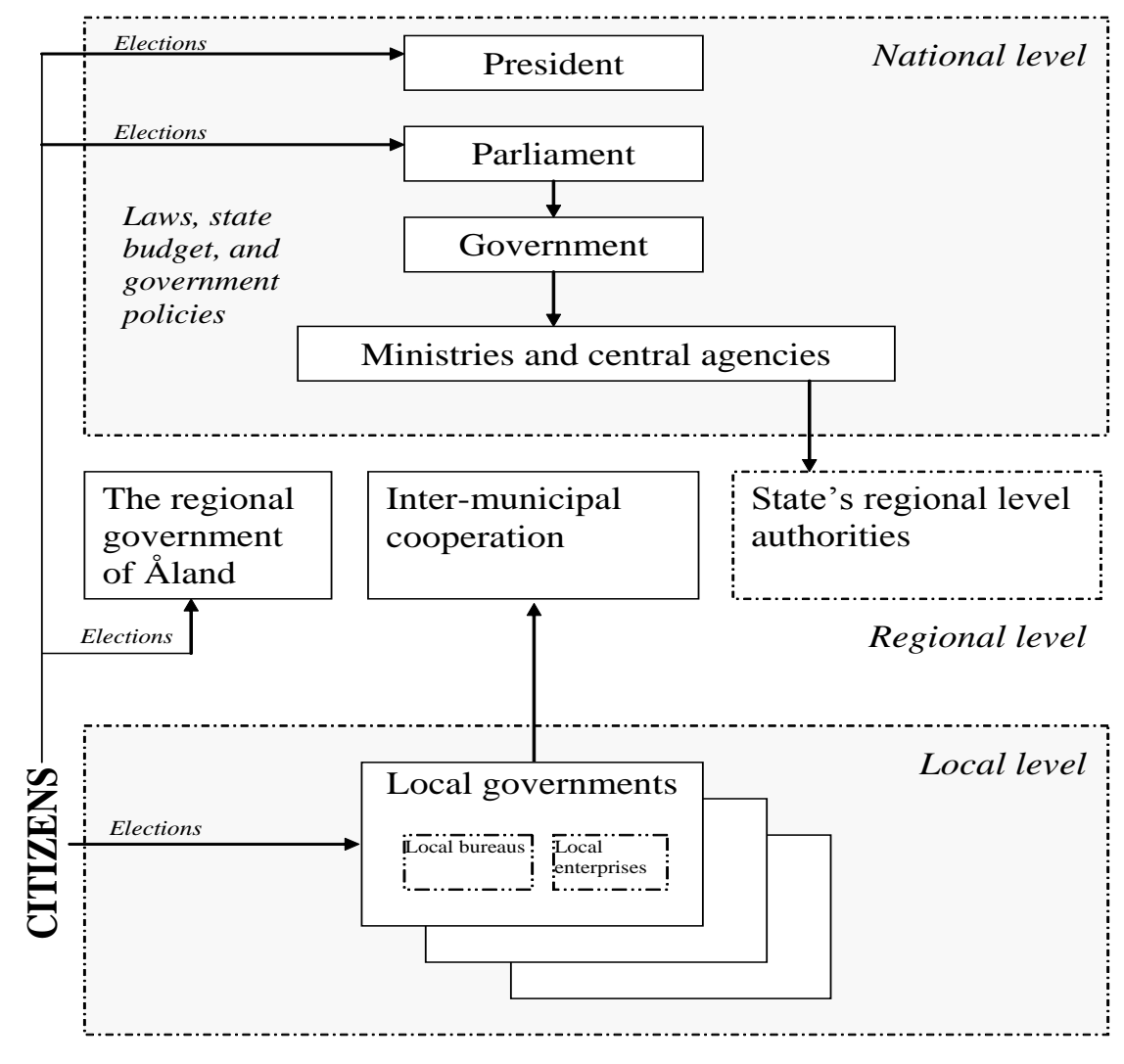

Figure 1. Simplified diagram of the current governmental structures in Finland.

Finnish local governments are self-governing entities, protected by the Constitution. They have a general competence and decision-making authority in local affairs. Intergovernmental relations have evolved towards a kind of contingent relationship between local and central government, depending on the size of local authority, the political issue, the policy programme and the way the state applies steering mechanisms (Nyholm, 2011). 
In 2016 there are 313 local authorities in Finland, the average size being only slightly more than 17,000 inhabitants (median as low as 6,000 inhabitants). The supreme decision-making organ is the municipal council, which is elected by local residents. Local government is independent in its decision making, its most important source of revenues being municipal taxation levied at flat rates set by the council. About half of all local government expenditures are covered by local taxes with state grants of close to one-fifth (on the basics of Finnish local government, see www.localfinland.fi).

\section{Roots and forms of localist influence}

Historically, localism was prominent in Finland's nation-building process in the latter half of the 19th century, consolidating into the agrarian localism of the first half of the following century, and developing further during the post-World War II decades into a nation-wide, decentralised welfare system implemented primarily through the modernised local authorities and joint local authorities (Andersson and Sjöblom, 2013).

Politically, the Centre Party of Finland has been the core of agrarian politics and a primary advocate of local self-government. From the early 1950s until the late 1980s the Centre Party held political power in tandem with the Social Democrats and more recently with the conservative National Coalition Party. It was instrumental in designing national reforms (on party politics and territorial reforms, see e.g. Massetti and Toubeau, 2014).

The other pillar of modern localism is local government. As a provider of local public services with a huge share of national GDP and employment, it is a heavyweight player in the design and implementation of public sector reforms. The strong influence of local government comes from its traditional image as a forum for local democracy, policymaking and development. Finland is small country by population without markedly differing regional identities, hence justifying an elected regional tier of government has been difficult (the only exception being the autonomous region of Åland). As Finnish localism manifests itself notably through a representative system of government and the machinery that provides public services (see Hildreth, 2011), it is less a reflection of local identity than an expression of two freedoms: those of being safeguarded from central government intervention and being able to produce locally preferred services and other policy outcomes (cf. Pratchett, 2004). 
Major routes for local government interventions in territorial policies are illustrated in Figure 2, with modern localism as a special category between 'society centred' and 'state centred' approaches to policymaking analysis (Meier, 1991).

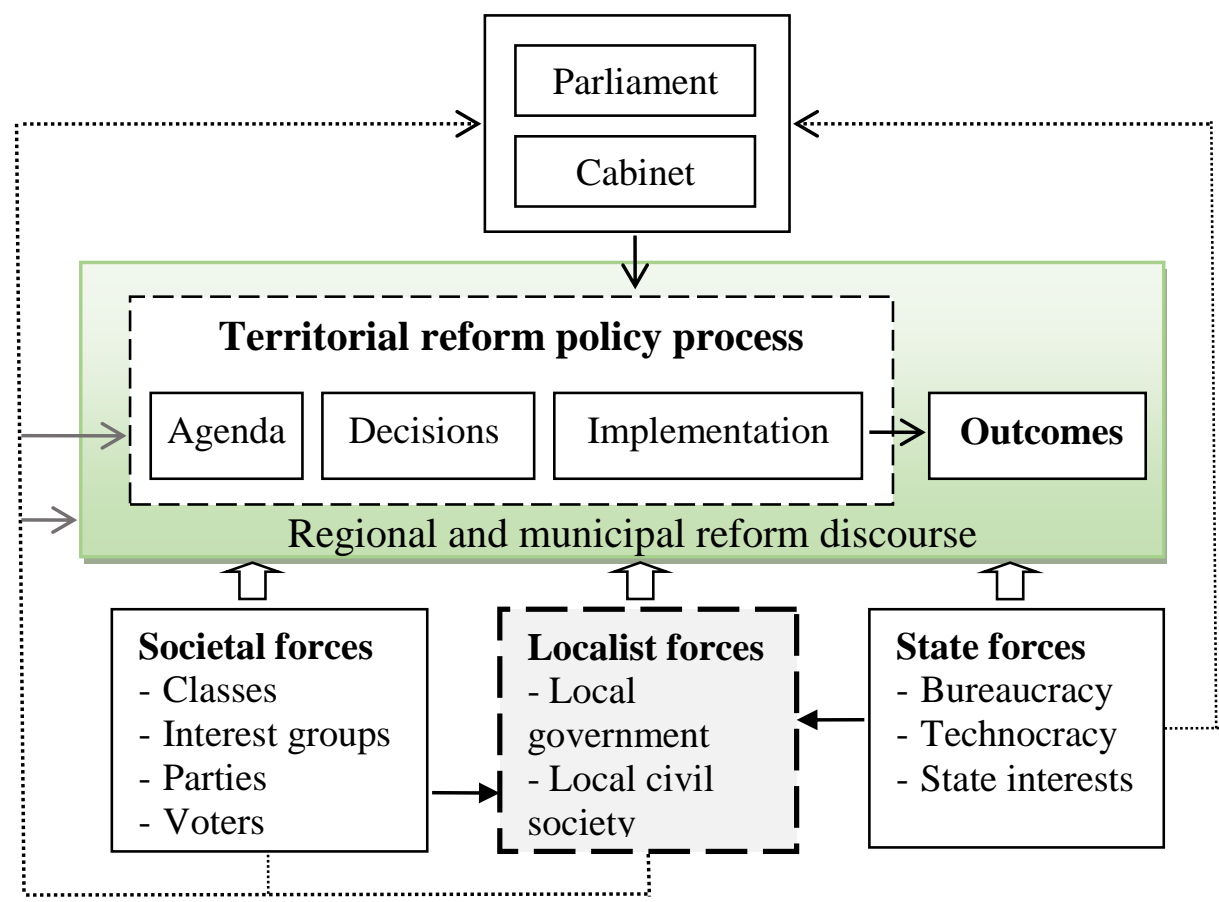

Figure 2. Illustration of routes of localist influence on territorial reforms.

Much of the lobbying in the interests of local governments is done by the Association of Finnish Local and Regional Authorities (AFLRA), which focuses on general interest representation. AFLRA and a few similar organisations influence the territorial reform agenda through direct political contacts and media as well as through their involvement in political and corporatist arrangements, such as national joint committees appointed by central government.

\section{Localism and territorial reforms in Finland}

The most important structural reform agenda after the Second World War was the so-called the Great Municipal Reform promoted by several successive governments since the early 1960s. It lasted some twenty years but achieved no notable territorial reform. It is significant that the strong hold maintained on local self-government was a decisive argument blocking proposed large-scale municipal mergers (Kull, 2009). 
The next major reform, the Free Municipality Experiment 1989-1996, emulated other Nordic countries in allowing bottom-up change, partnerships and streamlining of municipal organisations (Baldersheim and Ståhlberg, 1994). A clear indication of the sentiment in the early 1990s was the finding of a national committee of enquiry on regional government that there was no need for democratic and autonomous regional government in Finland (Kull, 2009).

A new reform wave started in the 1990s from the need to strengthen regions within a European regional development framework. Finland's accession to the EU in 1995 was obviously a major event in the process. It necessitated the construction of institutional structures to administer European regional policy and EU structural funds in particular. To take care of these tasks the joint municipal authorities known as Regional Councils were created by merging inter-municipal associations with regional planning associations (there are currently 18 Regional Councils in mainland Finland).

This process also brought sub-regions into the picture, i.e. supplementary units of regional governance originally created in response to the needs of EU structural policy and its statistical requirements (i.e. LAU1 level of the classification of statistical territorial units of the EU). Even if collaboration within sub-regions was voluntary, it served as a collaborative learning process at the early stage of the institutionalisation of 'new regions' (Haveri, 2003). The sub-regions were officially abolished in 2014.

The 2000s was essentially the time of sub-regional cooperation, for beside the establishment of sub-regions, inter-municipal collaboration proliferated in many service sectors, such as municipal waste management. A sign of hard line policy appeared around the same time, as the government's decision on the Fire and Rescue Service Reform eventually resulted in the establishment of 22 fire and rescue areas, which became operational in 2002 (Kallio and Tolppi, 2012). On top of that, ministries initiated sectoral development projects, such as the SEUTU Project (2000-2008) and the Sub-region Project in Education (2003-2004). The SEUTU Project was the most important project relating to sub-regionalisation, even though its pick-and-mix approach was not particularly successful. It was terminated prematurely and formally incorporated into the then on-going Municipal and Service Structure Reform (Nyholm, 2008). 
The first experiment in democratically-elected regional government on Finland's mainland was known as The Regional Government Experiment in Kainuu. The experiment ran from 2005 to 2012, aiming to ensure access to health care, social services and educational services for all residents of a sparsely populated and remote region (Leskinen, 2005). In the Kainuu experiment a particular concern was whether a larger regional unit could achieve cost savings in service provision. The evaluation report shows that the experiment did indeed achieve cost savings with no evidence of this being at the expense of service quality (MoF, 2008; Hämäläinen and Moisio, 2011). Adoption of the new regional government model after the trial period required unanimous agreement among its constituent municipalities. That condition was not met, however, because a single municipality opposed continuation another demonstration of the extreme influence of localism on the Finnish political scene. One of the major deficiencies of this model seemed to be that the constituent municipalities used their own revenues to jointly cover its costs, making it more similar to a joint municipal authority than genuine regional government (Haveri et al., 2015).

All these reforms were mostly separately designed, demonstrating the piecemeal approach to the reform of regional structure (cf. Knox, 2002). We will next discuss the most important and illustrative reform agenda, Municipal and Service Structure Reform, and the following chain of events that led to the framework decision in 2015 to adopt elected regional government model nationwide.

\section{Municipal and Service Structure Reform and its aftermath}

\section{The Municipal and Service Structure Reform}

The Municipal and Service Structure Reform 2005-2011, known in Finland as the PARAS Project, set up by PM Matti Vanhanen's first cabinet aimed to ensure that local authorities had a sufficient structural and financial basis on which to provide services. In the cabinet's report to parliament the rationale of the reform was expressed as follows:

"The Government is to introduce a municipal and service structure reform. Taking into account special features of different areas, there is a need to guarantee a sufficient population base for services organised by local authorities. The reform will create a well-functioning service network and intensify collaboration between different service systems. --- Specialist medical services and other services requiring 
a large population base must be fused population-wise into sufficiently large [territorial] entities. (Sisäasiainministeriö, 2005).

This reform agenda included both mergers and inter-municipal cooperation, which were needed to form entities covering large functional areas. In its statement on the previously mentioned report, the Association of Finnish Local and Regional Authorities (AFLRA) emphasised that,

"the responsibility for organising the most important basic services will continue to be vested in local authorities in the future. Accordingly, it is important that the safeguarding of services is approached in a municipality-oriented fashion taking into account the functional entity of local government. Improvement in service efficiency cannot be built on the basis of sector-based, compulsory municipal cooperation." (AFLRA, 2005).

During the reform, the number of local authorities was reduced from 444 in 2004 to 336 in 2012, which was actually quite a significant change given the background of prevailing political realities.

The original reform included no policy option for compulsory amalgamations of municipalities. However, the situation changed when the Centre Party as the largest party lost its leading position to the National Coalition Party in the 2011 parliamentary elections. PM Jyrki Katainen's cabinet (2011-2014) prepared the required legislative amendment and implemented a couple of compulsory municipal mergers in 2014. Soon after this unpopular move the declining government dropped such a hard-line policy and continued to promote voluntary mergers - obviously another indication of the strong localist influence in the process.

In 2011 Prime Minister Katainen's cabinet promised a historically unique 'Great Municipal Reform', but its ambitious plans to radically reduce the number of local authorities by mergers failed. One of the main reasons for this failure was localism, which seemed to have extended its tentacles deep into the Finnish political system. As assessed retrospectively by an editorial in the major Finnish newspaper Helsingin Sanomat on 28 October 2015, "Local authorities aided by the Centre Party in opposition raised a terrible hullabaloo, and the cabinet lacked the political courage to implement compulsory mergers. Local government was left in peace - or so they thought - and attempts at reform were transferred to social and health care - 
--." (Helsingin Sanomat, 2015). This quotation crystallises the fate of Katainen's attempted territorial reform.

Establishment of social and health care and regional self-governing areas

The story did not end with the watered-down Municipal and Service Structure Reform. Quite the reverse, soon after it was actually time to turn a new page in Finnish territorial reform. The first sign of this change was the Social and Health Care Reform, which had been discussed for decades but gained impetus after the political pact between the government and opposition in March 2014 (Ministry of Social Affairs and Health, 2014). The pact remained seemingly imprecise, dictating only that the reform would be based on five large social and health care areas responsible for organising health and social services. The new Social and Health Care Reform was eventually abandoned in March 2015, however, as the Constitutional Law Committee found that it violated the democratic rights of citizens.

The consensus achieved on the direction of radical sectoral reform, though unconstitutional, proved that decisions on structural changes could actually be taken, which is an important sign in a situation in which the status quo had been fiercely protected by localist forces for decades. A new script for the forthcoming radical reform was written after the parliamentary elections by the new government, Prime Minister Juha Sipilä's centre-right cabinet, in May 2015. The Strategic Programme of Prime Minister Juha Sipilä's Government states that,

"The Government will prepare a solution for the arrangement of social welfare and health care (SOTE) services based on autonomous areas larger than a municipality. There will be a maximum of 19 areas.” (Prime Minister's Office, 2015).

The government removed the municipal mergers from the agenda and even refrained from giving local authorities any new duties or obligations in the government term 2015-2019. The diminution of the role of local government in services was stated as follows:

"The Government will promote a change in the role of the municipality of the future, from an arranger of services increasingly to a promoter of vitality, entrepreneurship and employment in its area." (Prime Minister's Office, 2015). 
In other words, local authorities would no longer serve as the main vehicle for providing welfare services. Institutionally, the focus was on regions:

"The primary solution is to centralize functions in terms of duties and authority in clear autonomous areas." (Prime Minister's Office, 2015).

Besides self-governing areas as a new locus of welfare services, the government's strategic policy document highlights new regionalism by emphasising the government's support for metropolitan areas and the capital region in particular in their quest for international competitiveness and business development (Prime Minister's Office, 2015).

The pieces of the puzzle began to fall into place in an integrated regional reform agenda. In November 2015 the government introduced a new plan for 18 regional self-governing areas and 15 social and health care areas (in Finnish sote-alue), which implies that three regional entities needed to collaborate with others in providing social and health care services. According to preliminary plans, welfare services will be organised by large self-governing regional entities with a democratic decision-making structure with the social and health care sector at its core, supplemented by various other regional services. From the point of view of long-lasting localism this decision is about to change everything, for in the future Finnish public administration will be organised at three levels, those of the state, self-governing regions and local authorities, the primary tasks being respectively night-watchman functions, welfare services and local vitality. The government has a plan to introduce this bill to parliament in October 2016, and the new structure is to be fully operational in 2019. (VN, 2015b).

What is striking here is the fact that the strategic government programme and the decision on territorial reform in November 2015 marked a change that seemingly put an end to the dominance of localism on territorial agenda. Retrospectively, it seems that the two decades from 1995 to 2015 were a succession of governmental efforts to tame localism. The straw that broke the camel's back was the competitiveness-oriented agenda of the centre-right government in the context of the looming financial crisis. The changes were deemed necessary and, with the backing of the required majority in parliament, their execution finally became politically possible. In terms of political gains, the Centre Party achieved with this reform a fairly large number of self-governing regions, which resonates with its rural roots and political support in different parts of Finland, whereas the political right got the 
economies of scale, partial recentralisation of budget control, and prospects for increasing consumer choice and competitive bidding in the provision of welfare services.

\section{Discussion}

The assertive localism contributed not only to the emergence of various forms of bottom-up regionalisation but also had a considerable effect on the top-down reforms. The most dramatic examples of the latter are the termination of the Regional Government Experiment in Kainuu and the shelved Municipal and Service Structure Reform, both introduced in the mid-2000s.

Although successive governments in the last twenty years have considered local governments too small to tackle future challenges, they have been unable to design and implement any comprehensive territorial reform. Rather, there has been a piecemeal approach to regionalisation, which eventually brought about a messy middle-tier governance field. However, the pieces of the puzzle started to form a more integrated local-regional setting around 2015, due to the political decision of Sipilä's centre-right government to introduce new regional self-governing areas and social and health care areas.

The rise of new regionalism and its deviation from traditional localism is summarised in Table 1. At the risk of oversimplification, the 1980s was the last decade of traditional localism and the 2000s saw strong tendencies for both mergers (promoted by the Municipal and Service Structure Reform) and a search for a suitable model for regional government (in the Regional Government Experiment in Kainuu), the 1990s being a decade of transition. This transitional period saw the rise of both regions and sub-regions, essentially within the EU framework, which seemed to give an impetus to a stronger regionalisation agenda for the next decades. 
Table 1. Transition from decentralised to regionalised Finnish public administration.

\begin{tabular}{|c|c|c|}
\hline & Modern decentralised system & New regionalised system \\
\hline Historical period & 1960s to the mid-1990s & From the mid-1990s onwards \\
\hline Underlying ideology & Localism & New regionalism \\
\hline Framing policy & $\begin{array}{l}\text { Welfare policy; universalism; } \\
\text { public service expansion }\end{array}$ & $\begin{array}{l}\text { Competitiveness policy; } \\
\text { efficiency; austerity } \\
\text { measures }\end{array}$ \\
\hline $\begin{array}{l}\text { Geographical reference } \\
\text { area }\end{array}$ & Local community & Functional area \\
\hline Basic service area & Local authority's jurisdiction & Large municipality / region \\
\hline $\begin{array}{l}\text { Elected regional } \\
\text { government }\end{array}$ & None (except Aland) & $\begin{array}{l}\text { Experimented 2005-2012 in } \\
\text { Kainuu; decision to introduce } \\
\text { self-governing regions } \\
\text { (2015) }\end{array}$ \\
\hline
\end{tabular}

When analysed within an institutionalist framework, it is obvious that Finland's EU accession was a major event that paved the way for regionalisation. A more decisive milestone was the parliamentary elections and the subsequent formation of Sipilä's centre-right government in 2015, which eventually led to the downfall of the dominance of localism on the territorial policy agenda with the establishment of 18 regional self-governing areas and 15 social and health care areas. The micro-junctures during the past twenty years clearly showed the power of localist forces, but the contextual pressures and political shift - and especially the Centre Party's inclination to support strong regions and the National Coalition's stress on economies of scale - changed the tone of the coordinative discourse. Besides, the articulation of substantive content on the localist side did not sound particularly convincing against the widely felt strain and darkening economic outlook. The advantages of localism were increasingly judged against fears that without considerable efficiency gains the country would face economic disaster. As emphasised by Prime Minister Sipilä in his speech on government policy in June 2015, Finland is experiencing simultaneously debt and competitiveness crises, and therefore needs both considerable cost savings and major reforms. A Nordic economic wunderkind was even in danger of being placed under Brussels' budget control (VN, 2015a). Recent changes in territorial reform must be understood against such sentiment. The localism that was blocking a radical reform was thus effectively weakened by a blow to the very core of the power of representative localism, i.e. by transferring the main responsibility for organising welfare services to new regions.

What explains this paradigm shift? The socio-causation is obviously conjunctural, fusing contextual pressures, such as global and European financial crises, high national public debt and heightened awareness of the competitiveness challenge, with the electoral victory of 
centre, right-wing and populist parties in April 2015. This made radical institutional layering possible (the term refers to partial renegotiation of some elements of a given set of institutions, see Thelen, 2003). Within the political system the role of the Centre Party was decisive, as it became again the largest party in parliament. Many experts as well as the National Coalition as a major right-wing party in the cabinet, favoured larger areas and fewer units in the name of economies of scale, but could not sustain this against pressure from the Centre Party to keep the number of major regional units fairly large, ultimately reflecting the division of historical regions in Finland. Localist forces were neither able to veto the radical regionalisation agenda nor to negotiate it effectively against the government's pursuit of radical reform. Hypothetically, their next step would be boycott, which is an unlikely option given the Finnish consensual political culture and high level of compliance with norms. Rather, 'old' localism will most likely be transformed into Nordic-style 'new localism' in the local-regional interplay. The first sign of this is that AFLRA has already welcomed new regions under its umbrella (Kuntalehti, 2015).

\section{Conclusion}

Although the provision of public services in Finland has traditionally been assigned to local government, globalisation, the EU spatial development discourse, severe constraints on public finances and other related developments have prompted Finland to promote regionalisation, which, due to the small size of the population of the country and its assertive localism, has been pursued without an elected regional government.

Regionalisation in Finland from the early 1990s onwards was asymmetric because it was not based on the conventional argument for regional government but evolved as a regionalisation of governance legitimised by Finland's consensus-oriented political culture, strong localist sentiment and the prowess of relatively well-resourced multi-purpose local authorities and their associations. However, after the formation of the centre-right government in 2015, the time was ripe for a decisive reform of regional structure, which is currently under way. It is still vigorously debated, and the actual organisational and financial arrangements are still to a large extent unknown, but the tide seems to have turned for good. The period from 1995 to 2015 witnessed successive governments' endless efforts to tame the endemic localism. The straw that broke the camel's back was the crisis awareness and competitiveness-oriented agenda of the centre-right government, which made it increasingly difficult for localist forces to lobby for pro-status quo policy. 
The picture we painted of the case of Finland reveals some critical aspects of the dynamics of territorial reform, which, together with similar country cases, contributes to the accumulation of knowledge of the political and administrative realities of such reforms, including the motivation and impact of localist forces. A future challenge in this respect is to elaborate the institutionalist explanatory scheme further so as to better assess the nature of path dependence and the emergence of both incremental changes and critical junctures in the reforms as a reflection of the given structural and cultural contexts. In such a wider explanatory scheme it would be easier to provide a contextual view of the locus of localism. In addition, it is increasingly important to learn more about the interplay of exogenous and endogenous factors, which through the reform discourses affect social action and evidently also the social causation associated with the direction and outcomes of territorial reforms.

\section{References}

AFLRA (2005) Lausunto valtioneuvoston selonteosta Parempaa palvelua, tehokkaampaa hallintoa [Statement on the cabinet's report Better Service, More Efficient Administration]. Lausunto sisäasiainministeriölle 4.2.2005, dnro 75.2/90/2005. Helsinki: Suomen Kuntaliitto. Available at: http://www.kunnat.net/fi/Kuntaliitto/yleiskirjeet-

lausunnot/lausunnot/2005/Sivut/75.2-90-2005.aspx (accessed 3 March 2016).

Airaksinen J (2009) Hankala hallinnonuudistus. [The troublesome nature of administrative reform]. Acta Universitatis Tamperensis 1397. Tampere: Tampereen yliopisto.

Airaksinen J and Haveri, A (2012) How do local governments change? Variations in time and place for conflicts in different reforms. Kunnallistieteellinen aikakauskirja 40(4): 301-312.

Amenta E (2009) Making the Most of an Historical Case Study: Configuration, Sequence, Casing, and the US Old-Age Pension Movement. In: Byrne D and Ragin CC (eds) The SAGE Handbook of Case-Based Methods. London: Sage, pp. 351-366.

Amenta E and Ramsey KM (2010) Institutional Theory. In: Leicht KT and Jenkins JC (eds) Handbook of Politics: State and Society in Global Perspective. New York: Springer, pp. 1539.

Andersson K and Sjöblom S (2013) Localism in Finland: The changing role and current crisis of the Finnish municipal system. Local economy 28(3): 240-256.

Bailey SJ, Valkama P and Salonen S (2014) The EU's Public Finance Crisis: Causes, Consequences and Cure. Public Money and Management 34(2): 83-90.

Baldersheim H and Ståhlberg K (eds) (1994) Towards the self-regulating municipality: Free communes and administrative modernization in Scandinavia. Brookfield, VT: Dartmouth Publishing Company. 
Barnes WR and Foster KA (2012) Toward a More Useful Way of Understanding Regional Governance. A paper for presentation at the September 2012 conference of the European Urban Research Association, Vienna, Austria. Available at: http://brr.berkeley.edu/wp-content/uploads/2012/10/Barnes-Foster-Toward-a-more-usefulway-of-understanding-regional-governance.pdf (accessed 12 October 2015).

Bertrana X and Heinelt H (2013) The Second Tier of Local Government in the Context of European Multi-Level Government Systems: Institutional setting and prospects for reform. Revista catalana de dret public 46: 73-89.

Blomqvist P and Bergman P (2010) Regionalisation Nordic Style: Will Regions in Sweden Threaten Local Democracy? Local Government studies 36(1): 43-74.

Briffault R (1999) Localism and Regionalism. Columbia Law School, Public Law and Legal Theory Working Paper No. 1, August 1999. Available at: http://dx.doi.org/10.2139/ssrn.198822 (accessed 12 October 2015).

Bukowski JJ (2000) Complexity Matters: The Re-distribution of Authority in Spain and Portugal. In: Bukowski JJ and Rajagopalan S (eds) Re-distribution of Authority: A CrossRegional Perspective. Westport, CT: Praeger, pp. 93-121.

Capoccia G and Kelemen D (2007) The study of critical junctures: theory, narrative and counterfactuals in historical institutionalism. World Politics 59(3): 341-369.

Chorianopoulos I (2012) State spatial restructuring in Greece: forced rescaling, unresponsive localities. European Urban and Regional Studies 19(4): 331-348.

Gains F, John P and Stoker G (2005) Path Dependency and the Reform of English Local Government. Public Administration 83: 25-45.

Griffin L (1992) Temporality, Events, and Explanation in Historical Sociology: An Introduction. Sociological Methods \& Research 20(4): 403-427.

Hartwich O (2013) A Global Perspective on Localism. Occasional Paper. Wellington: The New Zealand Initiative and LGNZ. Available at: http://www.lgnz.co.nz/assets/Publications/A-global-perspective-on-localism.pdf (accessed 1 March 2016).

Haveri A (2003) Intermunicipal Cooperation as a Part of Local Governance. Finnish Local Government Studies 4: 316-325.

Haveri A (2006) Regional reorganisation in Finland: Local-level strategic choice or forced amalgamation. In: Salet WGM (ed) Synergy in Urban Networks: European Perspectives and Randstad Holland. The Hague: SDU Publishers, pp. 227-247.

Haveri A, Airaksinen J and Jäntti A (2015) The Kainuu Regional Experiment: Deliberate and unintended effects of scaling local government tasks to the regional level. Scandinavian Journal of Public Administration 19(4): 29-47.

Helsingin Sanomat (28 October 2015) Suomeen tulee sittenkin suuri kuntauudistus [Finland will have its Great Municipal Reform, after all]. Pääkirjoitus (editorial), Teija Sutinen,

Helsingin Sanomat, 28.10.2015, päivitetty 2.11.2015. Available at:

http://www.hs.fi/paakirjoitukset/a1445922363340 (accessed 3 March 2016). 
Henning M, Stam E and Wenting R (2013) Path Dependence Research in Regional Economic Development: Cacophony or Knowledge Accumulation? Regional Studies 47(8): 1348-1362.

Hildreth P (2011) What is localism, and what implications do different models have for managing the local economy? Local Economy 26(8): 702-714.

Howlett M (2003) Administrative styles and the limits of administrative reform: A neoinstitutional analysis of administrative culture. Canadian Public Administration 46: 471-494.

Hämäläinen K and Moisio A (2011) Kainuun hallintokokeilun kustannusvaikutukset [Cost effectiveness of Kainuu Regional Self-Government Experiment]. VATT Muistiot 16. Helsinki: Valtion taloudellinen tutkimuskeskus.

Hörnström L (2010) Redistributive regionalism: Narratives on regionalisation in the Nordic periphery. Research Report 2010:2. Umeå, Sweden: Umeå University. Available at: http://www.diva-portal.org/smash/get/diva2:318821/FULLTEXT01.pdf (accessed 12 October 2015).

Hörnström L (2013) Strong Regions within the Unitary State: The Nordic Experience of Regionalization. Regional and Federal Studies 23(4): 427-443.

Kallio O and Tolppi R (2012) Alueellinen pelastustoimi seitsemän toimintavuoden jälkeen Muutoksia ja kokemuksia aluepelastuksesta 2004-2010 [Regional Rescue Service after Seven Years of Operation]. Seurantatutkimuksen 3. vaiheen loppuraportti. Helsinki: Suomen Kuntaliitto.

Kettunen P (2009) Regional policy-making in Finland: governance of networks or just topdown steering? Croatian Public Administration - a Journal for Theory and Practice of Public Administration 9: 107-123.

Kettunen P and T Kungla (2005) Europeanization of sub-national governance in unitary states: Estonia and Finland. Regional and Federal Studies 3: 353-378.

Kingdon J (1984) Agendas, Alternatives, and Public Policies. New York: Longman.

Kingston C and Caballero G (2009) Comparing theories of institutional change. Journal of Institutional Economics 5(2): 151-180.

Knox C (2002) Public Service Reform. Briefing Paper for the Review of Public Administration (Northern Ireland). 26 September 2002. Belfast, Northern Ireland: The Review of Public Administration (RPA).

Kull M (2009) Local and Regional Governance in Finland: A Study on Institutionalisation, Transformation and Europeanization. Halduskultuur 10: 22-39.

Kuntalehti (20 November 2015) Koskinen: Itsehallintoalueet sopivat Kuntaliittoon [Koskinen: Self-governing areas are fit to Municipal Association]. Kuntalehti 20.11.2015, by Eero Karisto. Available at: http://kuntalehti.fi/kuntauutiset/paatoksenteko/koskinen-sote-alueetsopivat-kuntaliittoon/ (accessed 5 March 2016). 
Leskinen H (2005) Self-government experiment in Kainuu region. 120105HL. Available at: http://www.kainuu.fi/fi_tied04/Self_government_experiment_020105.doc (accessed 12 October 2015).

Lieberman ES (2001) Causal inference in historical institutional analysis: A specification of periodization strategies. Comparative political studies 34(9): 1011-1035.

Lind T (2013) Regional policy and the role of the regional level in Finland, Norway and Sweden: A comparative study. In: Lundmark L and Sandström C (ed) Natural resources and regional development theory. Umeå universitet GERUM Kulturgeografisk arbetsrapport. Umeå: Institutionen för geografi och ekonomisk historia, pp. 52-68.

Lähteenmäki-Smith K et al. (eds) (2006) Local and Regional Reform Processes in Norden. Helsinki: The Association of Finnish Local and Regional Authorities.

Mahoney J (2000) Path Dependence in Historical Sociology. Theory and Society 29(4): 507548.

Malloy TH (2013) Nordic (Minority) Autonomies and Territorial Management in Europe: Empowerment through Regionalisation? International Journal on Minority and Group Rights 20: 85-106.

Markey S, Pierce JT, Vodden K and Roseland M (2005) Second Growth: Community Economic Development in Rural British Columbia. Vancouver: UBC Press.

Massetti E and Toubeau S (eds) (2014) The Party Politics of Territorial Reforms in Europe. Abingdon, UK: Routledge.

Mayr A (ed) (2008) Language and Power: An introduction to institutional discourse. London: Continuum International Publishing Group.

Meier G (ed) (1991) Politics and policy making in developing countries. San Francisco: International Center for Economic Growth Press.

Meklin P and Pekola-Sjöblom M (eds) (2013) The reform to restructure municipalities and services in Finland: A research perspective. Helsinki: Association of Finnish Local and Regional Authorities.

Mennola E (1999) The institutionalization of regions in Finland: a historical perspective. Kunnallistieteellinen aikakauskirja 27(3): 385-395.

Ministry of Social Affairs and Health (2014) Social welfare and health care reform. Helsinki: Ministry of Social Affairs and Health. Available at: http://www.stm.fi/en/ministry/strategies/service_structures (accessed 12 October 2015).

MoF (2008) Regional self-government experiment in Kainuu region; III intermediate report. Helsinki: Ministry of Finance.

Moore C (1991) Reflections on the New Local Political Economy: resignation, resistance and reform. Policy \& Politics 19(2): 73-86.

Moore M (2014) Localism: a philosophy of government. Fourth edition. Arkansas: The Ridge Enterprise Group. 
Nyholm I (2008) Keskijohto kuntamuutoksen näkijänä ja kokijana. [Middle management as the observer and participant in local government change]. Acta Electronica Universitatis Tamperensis: 705. ACTA-sarja. Helsinki: Suomen Kuntaliitto.

Nyholm I (2011) Kunta-valtio-suhteen muodonmuutos - linjakkaasta liitosta monimuotoisten mekanismien määrittämäksi kokonaisuudeksi [Metamorphosis of the local government-state relationship: from streamlined union to a whole determined by multiple mechanisms]. In: Haveri A, Stenvall J and Majoinen K (eds) Kunnallisen itsehallinnon peruskivet. Helsinki: Suomen Kuntaliitto, pp. 128-140.

OECD (2014) OECD Regional Outlook 2014: Regions and Cities: Where Policies and People Meet. OECD Publishing. Available at: http://dx.doi.org/10.1787/9789264201415-en (accessed 3 March 2016).

Paasi A and Zimmerbauer K (2011) Theory and practice of the region: a contextual analysis of the transformation of Finnish regions. Treballs de la Societat Catalana de Geografia 71-72: 163-178.

Page EC (1991) Localism and Centralism in Europe: The Political and Legal Bases of Local Self-Government. Oxford: Oxford University Press.

Pedersen HH (2013) Is measuring interest group influence a mission impossible? The case of interest group influence in the Danish parliament. Interest Groups \& Advocacy 2(1): 27-47.

Phillips N, Lawrence TB and Hardy C (2004) Discourse and Institutions. Academy of Management Review 29(4): 635-652.

Pratchett L (2004) Local Autonomy, Local Democracy and the 'New Localism'. Political Studies 52(2): 358-375.

Prime Minister's Office (2015) Finland, a Land of Solutions: Strategic Programme of Prime Minister Juha Sipilä’s Government, 29 May 2015. Government Publications 12/2015. Available at:

http://valtioneuvosto.fi/documents/10184/1427398/Ratkaisujen+Suomi_EN_YHDISTETTY_ netti.pdf/8d2e1a66-e24a-4073-8303-ee3127fbfcac (accessed 7 March 2016).

Pritoni A (2014) How To Measure Interest Group Influence: Evidence From Italy. ECPR Joint Sessions of Workshops 2014. Universidad de Salamanca, España, 10-15 April 2014. Available at: http://ecpr.eu/filestore/paperproposal/2dc6215d-86ad-4dbb-b157b4895df37fe9.pdf (accessed 3 March 2016).

Prytherch D (2009) New Euroregional territories, old Catalanist dreams? Culture and economy in the discursive construction of the Mediterranean Arc. European Urban and Regional Studies 16(2): 131-145.

Rees J and Rose N (2015) New 'new localism' or the emperor's new clothes: diverging local social policies and state-voluntary sector relations in an era of localism. Voluntary Sector Review 6(1): 81-91.

Schmidt VA (2008) Discursive Institutionalism: the explanatory power of ideas and discourse. Annual Review of Political Science 11: 303-326. 
Schmidt VA (2010) Taking ideas and discourse seriously: explaining change through discursive institutionalism as the fourth 'new institutionalism'. European Political Science Review 2(1): 1-25.

Shand W (2015) Exploring institutional change: The contribution of co-production to shaping institutions. IIED Working Paper, December 2015. London: International Institute for Environment and Development.

Sisäasiainministeriö (2005) Parempaa palvelua, tehokkaampaa hallintoa [Better service, more efficient administration]. Sisäasiainministeriön julkaisu 15/2005. Available at: http://www.intermin.fi/julkaisu/152005?docID=25011 (accessed 2 March 2016).

Steinmo S (2008) What is Historical Institutionalism? In: della Porta D and Keating M (eds) Approaches and Methodologies in the Social Sciences. Cambridge, UK: Cambridge University Press, pp. 118-138.

Stewart J (1983) Local Government: The Conditions for Local Choice. Institute of Local Government Studies. London: George Allen \& Unwin.

Stoker G (1991) Introduction: trends in European local government. In: Batley R and Stoker $\mathrm{G}$ (eds) Local Government in Europe: trends and developments. Basingstoke: Palgrave Macmillan, pp. 1-20.

Streeck W and Thelen K (2005) Introduction: Institutional Change in Advanced Political Economies. In: Streeck W and Thelen K (eds) Beyond Continuity: Institutional Change in Advanced Political Economies. Oxford, UK: Oxford University Press, pp. 1-39.

Thelen K (2003) How institutions evolve: Insights from comparative historical analysis. In: Mahoney J and Rueschemeyer D (eds) Comparative Historical Analysis in the Social Sciences. New York: Cambridge University Press, pp. 208-240.

Tomblin SG (2007) Effecting change and transformation through regionalization: theory versus practice. Canadian Public Administration 50(1): 1-20.

Van Dijk TA (ed) (1997) Discourse as Social Interaction. London: Sage.

VN (2015a) Prime Minister Juha Sipilä's speech in Parliament on the strategic Government Programme. Government Communications Department, 2.6.2015. Helsinki: Valtioneuvosto. Available at: http://valtioneuvosto.fi/artikkeli/-/asset_publisher/paaministeri-juha-sipilastrategisen-hallitusohjelman-tiedonantokeskustelussa-eduskunnassa-2-62015?_101_INSTANCE_3wyslLo1Z0ni_groupId=10616\&_101_INSTANCE_3wyslLo1Z0ni _languageId=en_US

VN (2015b) Government decision on next steps in reform package on healthcare, social welfare and autonomous regions. Government Communications Department, 9.11.2015. Press release 591/2015. Helsinki: Valtioneuvosto. Available at:

http://valtioneuvosto.fi/artikkeli/-/asset_publisher/hallitus-paatti-sote-uudistuksen-jatkosta-jaitsehallintoalueista?_101_INSTANCE_3wyslLo1Z0ni_groupId=10616\&_101_INSTANCE_3 wyslLo1Z0ni_languageId=en_US (accessed 7 March 2016).

Yin RK (2008) Case Study Research: Design and Methods. Fourth Edition. London: Sage. 